\title{
Can we predict mortality in patients with necrotizing fasciitis using conventional scoring systems?
}

\author{
Necdet Fatih Yaşar, M.D., ${ }^{1}$ Mustafa Ufuk Uylaş, M.D., ${ }^{1}$ Bartu Badak, M.D.,, ${ }^{1}$ Uğur Bilge, M.D., ${ }^{2}$ \\ Setenay Öner, M.D., ${ }^{3}$ Enver İhtiyar, M.D., ${ }^{1}$ Tarık Çağa, M.D., ${ }^{1}$ Ercüment Paşaoğlu, M.D. ${ }^{1}$
}

\begin{abstract}
${ }^{1}$ Department of General Surgery, Eskişehir Osmangazi University, Eskişehir-Turkey ${ }^{2}$ Department of Family Medicine, Eskişehir Osmangazi University, Eskişehir-Turkey

${ }^{3}$ Department of Biostatistics, Eskişehir Osmangazi University, Eskişehir-Turkey
\end{abstract}

\begin{abstract}
BACKGROUND: This study compared the predictive accuracy of four scoring systems, namely Acute Physiology and Chronic Health Evaluation II (APACHE II), Sequential Organ Failure Assessment (SOFA), Simplified Acute Physiology Score II (SAPS II), and Mortality in Emergency Department (MEDS), for estimating prognosis in patients with necrotizing fasciitis.
\end{abstract}

METHODS: Seventy-four patients who presented with necrotizing fasciitis were retrospectively examined. The ability of the scoring systems to predict mortality was assessed by comparing the estimated mortality rates in mortality groups (survivors/non-survivors), and mortality rates among survivors and non-survivors with an estimated mortality of $>10 \%, 30 \%$, and $50 \%$ in the scoring systems were compared in pairs.

RESULTS: Estimated mortality rates in the survivor and non-survivor groups were different for all the scoring systems. The estimated mortality rates of APACHE II and SAPS II were much closer to the actual mortality rates than the other two scoring systems. When the predicted mortality rates were analyzed as limits for a mortality risk, the predicted mortality rate by APACHE II was superior to that by SAPS II.

CONCLUSION: The studied scoring systems had significantly higher predicted mortality rates in non-survivors than in survivors; however, they all underestimated the mortality rate. APACHE II and SAPS II were relatively superior for estimating mortality in patients with necrotizing fasciitis. APACHE II rather than the other scoring systems should be currently used.

Keywords: APACHE I; MEDS; necrotizing fasciitis; SAPS II; SOFA.

\section{INTRODUCTION}

Necrotizing soft tissue infection defines a group of necrotizing infections of the skin, soft tissues, and muscles and is described as necrotizing fasciitis when it rapidly progresses through fascial planes. It may develop in the upper and lower extremities, perineum and genital area, and abdominal wall. The clinical course may be swift owing to polymicrobial infection and synergy that cause the destruction of the fascia

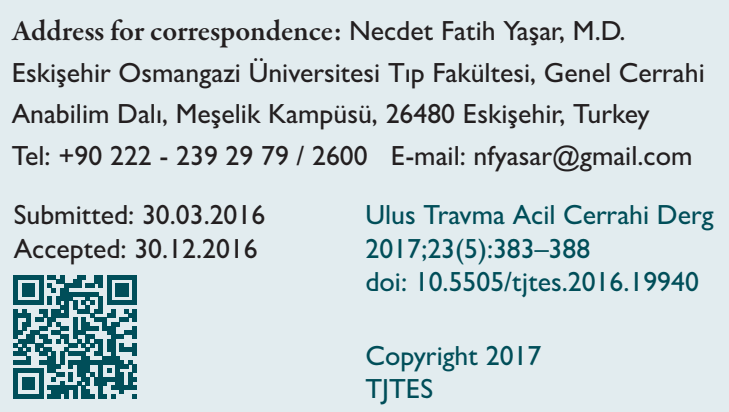

at a rate of approximately $2-3 \mathrm{~cm} / \mathrm{h}^{[1,2]}$ Therefore, the early diagnosis of necrotizing fasciitis is life-saving, whereas any delay may result in more extensive surgery, higher amputation rates, and higher mortality rates. Mortality rates are approximately $25 \%$ and if untreated, reach $100 \%$. ${ }^{[3,4]}$ Therefore, correctly assessing the severity of the illness to predict the mortality and morbidity of patients with necrotizing fasciitis is essential.

Acute Physiology and Chronic Health Evaluation II (APACHE II) and Simplified Acute Physiology Score II (SAPS II) scores are calculated using the worst physiological variables, which were collected within the first $24 \mathrm{~h}$ of admission to the intensive care unit (ICU) and correlated to the highest number of points. ${ }^{[5,6]}$ Unlike APACHE II and SAPS II systems, Sequential Organ Failure Assessment (SOFA) was designed to approximately estimate mortality risk, e.g., SOFA score between 0 and 6 denoted a mortality risk of $<10 \%$, whereas that between 15 and 24 predicted a mortality risk of $>90 \% .{ }^{[7,8]}$ The Mortality in Emergency Department (MEDS) score has been 
validated as a predictor of 28-day mortality in patients who present to the emergency department (ED) with systemic inflammatory syndrome. ${ }^{[9]}$

According to a Medline research, the APACHE II system was the severity score most often used for necrotizing fasciitis, ${ }^{[10-13]}$ whereas the SOFA and SAPS systems was less often used to predict mortality in patients with necrotizing fasciitis, ${ }^{[14]}$ with the MEDS scoring system never being used. Furthermore, no study has compared the scoring systems for predicting the mortality in patients with necrotizing fasciitis. Thus, this retrospective study compared the APACHE II, SOFA, SAPS, and MEDS scoring systems for predicting mortality and their correlation with hospitalization duration.

\section{MATERIALS AND METHODS}

The study protocol was approved by the local ethical committee.

The APACHE II, SOFA, SAPS II, and MEDS scores were calculated on the basis of the worst laboratory values and clinical findings recorded during the first $24 \mathrm{~h}$ of admission to the ICU using online calculators available at the following links: http:// clincalc.com/lcuMortality/APACHEll.aspx, http://clincalc.com/ IcuMortality/SOFA.aspx, http://clincalc.com/lcuMortality/SAPSIl.aspx, and http://emcalculator.com/meds, respectively.

\section{Statistical Analysis}

The medical reports of 98 patients who presented with necrotizing fasciitis between January 2008 and December 2015 were retrospectively examined. The diagnosis of necrotizing fasciitis was confirmed by surgical exploration and pathological analysis of debrided tissues in all patients. Of all patients, 74 with available data were included in the study. Statistical analysis was performed using the SPSS software program version 2 I (SPSS Inc., Chicago, IL). Because the differences between mortality rates estimated by different scoring systems were too wide and because the SOFA scoring system estimates mortality rates in ranges, we categorized patients into the following four groups according to estimated mortality rates: group I, estimated mortality rates of $<10 \%$; group 2 , estimated mortality rates between $10 \%$ and $29 \%$; group 3 , estimated mortality rates between $30 \%$ and $49 \%$; and group 4 , estimated mortality rates of $\geq 50 \%$.

The ability of the scoring system to predict mortality was assessed by comparing estimated mortality rates in mortality groups (survivors/non-survivors) using chi-square test (Monte Carlo). After analyzing the ability of the scoring systems, mortality rates between survivors and non-survivors with estimated mortality rates of $>10 \%, 30 \%$, and $50 \%$ in the different scoring systems were compared in pairs by Pearson's chisquare test. Furthermore, correlation between the duration of ICU admission, duration of hospitalization, and scores of the scoring systems among all patients and among survivors were analyzed.

\section{RESULTS}

Patient characteristics, mortality rates, durations of ICU admissions, durations of hospitalization, and results of the scorings systems are all presented in Table I.

Estimated mortality rates in the survivor and non-survivor groups were different for all the scoring systems, including APACHE II, SOFA, SAPS II, and MEDS ( $p<0.00 \mathrm{I}, \mathrm{p}<0.0 \mathrm{I}$, $\mathrm{p}<0.00 \mathrm{I}$, and $\mathrm{p}<0.0 \mathrm{I}$, respectively).

The actual mortality rates in the estimated mortality groups are presented in Table 2, which revealed that the predictions of the APACHE II and SAPS II scoring systems were closer to the actual mortality rates. Other than prediction accuracy, we also analyzed the predicted mortality rates as limits for mortality risk and presented the ratios of non-survivors to patients with predicted mortality rates of $>10 \%, 30 \%$, and $50 \%$ and the ratios of survivors to patients with predicted mortality rates of $<10 \%, 30 \%$, and $50 \%$ in Table 3 .

The significant differences between the ratios of non-survivors to patients with predicted mortality rates of $>10 \%, 30 \%$, and $50 \%$ and the ratios of survivors to patients with predicted mortality rates of $<10 \%, 30 \%$, and $50 \%$ are presented in Tables 4 and 5, respectively.

There were no correlations between the scores of all the scoring systems (APACHE II, SOFA, MEDS, and SAPS II) and duration of hospitalization and duration of ICU admission among survivors $(r=0.075, r=0.185, r=0.041$, and $r=0.201$, respectively, and $r=0.075, r=0.170, r=0.015$, and $r=0.143$, respectively; $p>0.05$ for all).

Mortality rates and scores of the predictive scoring systems for patients with necrotized peritoneum and other sites, including abdomen, groin, lower limb, and breast, were not different (Table 6).

\section{DISCUSSION}

Necrotizing fasciitis is uncommon but has a very high mortality and complication rate. In this study, the mortality rate was approximately the same as that recently reported. ${ }^{[4]}$ However, the rate was greater than that predicted by the scoring systems. Severity scoring systems and mortality prediction have been developed for managing hospital resources and evaluating quality of care and therapeutic interventions; thus, the accuracy of these scoring systems is essential.

As observed in other studies, severity scores and estimated mortality rates in the survivor and non-survivor groups were 
Table I. Patient demographic data, infection sites, comorbidities, estimated mortality rates, and actual mortality rates in patients with necrotizing fasciitis

\begin{tabular}{|c|c|c|c|c|c|}
\hline & & $\mathbf{n}$ & $\%$ & & $\mathbf{p}$ \\
\hline \multirow[t]{2}{*}{ Sex } & Females & 22 & 29.7 & & \\
\hline & Males & 52 & 70.3 & & \\
\hline Mortality & & 22 & 29.7 & & \\
\hline \multirow[t]{4}{*}{ Site of infection } & Perineum \& genitalia & 48 & 64.9 & & \\
\hline & Abdomen \& groin & 20 & 27.0 & & \\
\hline & Lower limb & 5 & 6.8 & & \\
\hline & Breast & 1 & 1.4 & & \\
\hline \multirow[t]{8}{*}{ Comorbidities } & Diabetes mellitus & 27 & 37.5 & & \\
\hline & Coronary artery disease & 18 & 25 & & \\
\hline & Hypertension & 13 & 18.1 & & \\
\hline & Chronic kidney disease & 4 & 5.6 & & \\
\hline & Chronic obstructive pulmonary disease & 3 & 4.2 & & \\
\hline & Hematologic malignancy & 4 & 5.6 & & \\
\hline & Metastatic malignancies & 14 & 19.4 & & \\
\hline & & Median & $25 \%$ & $75 \%$ & \\
\hline Age & & 57.5 & 43 & 66 & \\
\hline LRINEC scores in survivors & & 5 & 3 & 7 & $>0.05$ \\
\hline LRINEC scores in nonsurvivors & & 5.5 & 2.75 & 9.5 & \\
\hline Duration of ICU admission (all patients) & & 6 & 0 & 15.25 & \\
\hline Duration of hospitalization (all patients) & & 17 & 10 & 27 & \\
\hline Duration of ICU admission (survivors) & & 0 & 0 & 10 & \\
\hline Duration of hospitalization (survivors) & & 17 & 10 & 26 & \\
\hline APACHE II (all patients) & Severity score & 9 & 4 & 15 & \\
\hline (survivors) & Estimated mortality: \% & 9.9 & 5.1 & 22.3 & \\
\hline \multirow[t]{2}{*}{ (nonsurvivors) } & Severity score & 6.5 & 3 & 10 & $<0.001$ \\
\hline & Severity score & 16 & II & 22.5 & \\
\hline SOFA (all patients) & Severity score & 2 & 0 & 8 & \\
\hline (survivors) & Estimated mortality: \% & $<10$ & $<10$ & $15-20$ & \\
\hline \multirow[t]{2}{*}{ (nonsurvivors) } & Severity score & 0.5 & 0 & 3 & $<0.001$ \\
\hline & Severity score & 5 & 2.75 & 7.25 & \\
\hline SAPS II (all patients) & Severity score & 30 & 21 & 41 & \\
\hline (survivors) & Estimated mortality: \% & 10.6 & 4.2 & 26.6 & \\
\hline \multirow[t]{2}{*}{ (nonsurvivors) } & Severity score & 24 & 18.25 & 32.75 & $<0.001$ \\
\hline & Severity score & 39 & 30 & 48.5 & \\
\hline MEDS (all patients) & Severity score & 6 & 3 & 9 & \\
\hline (survivors) & Estimated mortality: \% & 4.4 & I.I & 9.3 & \\
\hline \multirow[t]{2}{*}{ (nonsurvivors) } & Severity score & 3 & 0 & 7.5 & $<0.001$ \\
\hline & Severity score & 9 & 6 & 13.25 & \\
\hline
\end{tabular}

P: The significance of the difference between survivors and non survivors. LRINEC: Laboratory Risk Indicator for Necrotizing Fasciitis; ICU: Intensive care unite; APACHE II: Acute Physiology and Chronic Health Evaluation II; SOFA: Sequential Organ Failure Assessment; SAPS II: Simplified Acute Physiology Score II; MEDS: Mortality in Emergency Department.

different for all the scoring systems. ${ }^{[13,14]}$ Because necrotizing fasciitis of the perineum and genitalia has a better prognosis than that of other body sites, we stratified the study by comparing mortality rates and the scores of four scoring systems in patients with necrotizing fasciitis of the perineum and genitalia and other parts, including the abdomen, groin, lower 
Table 2. Actual mortality rates in estimated mortality groups

\begin{tabular}{llcccc}
\hline Estimated mortality groups & & APACHE II & SOFA & SAPS II & MEDS \\
\hline Group I & $<10 \%$ & $4 / 40(10 \%)$ & $15 / 65(23.1 \%)$ & $3 / 36(8.3 \%)$ & $17 / 68(25 \%)$ \\
Group 2 & $10-29 \%$ & $8 / 19(42.1 \%)$ & $5 / 7(71.4 \%)$ & $11 / 24(45.8 \%)$ & $0 / 1(0 \%)$ \\
Group 3 & $30-49 \%$ & $6 / 11(54.5 \%)$ & $0 / 0$ & $4 / 10(40 \%)$ & $5 / 5(100 \%)$ \\
Group 4 & $\geq 50 \%$ & $4 / 4(100 \%)$ & $2 / 2(100 \%)$ & $4 / 4(100 \%)$ & \\
\hline
\end{tabular}

APACHE II: Acute Physiology and Chronic Health Evaluation II; SOFA: Sequential Organ Failure Assessment; SAPS II: Simplified Acute Physiology Score II; MEDS: Mortality in Emergency Department.

Table 3. Ratio of non-survivors to patients with predicted mortality rates of $>10 \%, 30 \%$, and $50 \%$ and that of survivors to patients with predicted mortality rates of $<10 \%, 30 \%$, and $50 \%$

\begin{tabular}{lcccc}
\hline Predicted mortality rates & APACHE II & SOFA & SAPS II & MEDS \\
\hline$\geq 10 \%$ & $18 / 34$ & $7 / 9$ & $19 / 38$ & $5 / 6$ \\
$\geq 30 \%$ & $8 / 11$ & $2 / 2$ & $8 / 14$ & $5 / 5$ \\
$\geq 50 \%$ & $4 / 4$ & $2 / 2$ & $4 / 4$ & $51 / 68$ \\
$<10 \%$ & $36 / 40$ & $50 / 65$ & $33 / 36$ & $52 / 69$ \\
$<30 \%$ & $50 / 63$ & $52 / 72$ & $46 / 60$ & $52 / 74$ \\
$<50 \%$ & $52 / 70$ & $52 / 72$ & $52 / 70$ & \\
\hline
\end{tabular}

APACHE II: Acute Physiology and Chronic Health Evaluation II; SOFA: Sequential Organ Failure Assessment; SAPS II: Simplified Acute Physiology Score II; MEDS: Mortality in Emergency Department.

limb, and breast. ${ }^{[4]}$ However, we did not observe any statistical difference, probably owing to late referrals to our clinic or severe comorbidities of the patients because our institution is a tertiary referral center.

Table 4. Comparisons of estimated mortality rate groups $<10 \%,<30 \%$, and $<50 \%$ among survivors

\begin{tabular}{lcccc}
\hline & APACHE II & SOFA & SAPS II & MEDS \\
\hline APACHE II & & n.s & $* *$ & n.s. \\
& & n.s & n.s. & n.s. \\
SOFA & & n.s & $*$ & \\
& n.s. & & n.s. & n.s. \\
& n.s. & & n.s. & n.s. \\
MEDS & n.s. & & n.s. & \\
& n.s. & n.s. & n.s. & \\
& n.s. & n.s. & n.s. & \\
SAPS II & **. & & & \\
& n.s. & n.s. & & n.s. \\
& $*$ & n.s. & & n.s. \\
\hline
\end{tabular}

" $p<0.05$ significantly different. " $p<0.01$ very significantly different. " $p<0.001$ extremely significantly different. APACHE II: Acute Physiology and Chronic Health Evaluation II; SOFA: Sequential Organ Failure Assessment; SAPS II: Simplified Acute Physiology Score II; MEDS: Mortality in Emergency Department; n.s.: Non-specific.
Our results showed that predicted mortality rates using the APACHE II and SAPS II scoring systems were more accurate than those using the SOFA and MEDS scoring systems. The median APACHE II score was 9.9, which was lower than that reported by Yilmazlar et al., which was 13.9; however, the mortality rate was also higher in their study (49\%). ${ }^{[1]}$ In contrast, the mean APACHE II score was 8.5 for survivors and 19.6 for non-survivors, and our results were close to those reported by Yilmazlar et al. (6.5 for survivors and 16 for nonsurvivors). The median SOFA and SAPS II scores were lower than those reported by Boyer et al. (30 vs. 37.2 and 2 vs. 4.7, respectively); similarly, the mortality rate in the current study was also lower (22\% vs. $40.6 \%){ }^{[14]}$ However, the mean SOFA and SAPS II scores for survivors and non-survivors were low in our study results (SOFA, 0.5 vs. 3 in survivors, 5 vs. 7.1 in non-survivors; SAPS II, 24 vs. 29.3 in survivors, 39 vs. 48.6 in non-survivors).

In this study, we assessed patients according to predicted mortality rates such as $<10 \%, 10 \%-29 \%, 30 \%-49 \%$, and $\geq 50 \%$. Among patients with predicted mortality rates of $<10 \%$, APACHE II and SAPS II were the only scoring systems with accurate predicted mortality rates, whereas SOFA and MEDS underestimated the actual mortality rates. However, among patients with predicted mortality rates of $>50 \%$, the scoring systems underestimated the mortality, which was actually $100 \%$. It was noteworthy that no patient had a predicted mortality rate of $>50 \%$ in the MEDS scoring system. 
Table 5. Comparison of mortality in estimated mortality groups $\geq 10 \%, \geq 30, \geq 50$, respectively among nonsurvivors

\begin{tabular}{|c|c|c|c|c|}
\hline & APACHE II & SOFA & SAPS II & MEDS \\
\hline \multirow[t]{3}{*}{ APACHE II } & & n.s. & n.s. & n.s. \\
\hline & & n.s. & $* * *$ & $* *$ \\
\hline & & n.s. & $* * *$ & \\
\hline \multirow[t]{3}{*}{ SOFA } & n.s. & & n.s. & n.s. \\
\hline & n.s. & & n.s. & n.s. \\
\hline & n.s. & & n.s. & \\
\hline \multirow[t]{2}{*}{ MEDS } & n.s. & n.s. & n.s. & \\
\hline & $* *$ & n.s. & $*$ & \\
\hline \multirow[t]{3}{*}{ SAPS II } & n.s. & n.s. & & n.s. \\
\hline & $* * *$ & n.s. & & n.s. \\
\hline & $* * *$ & n.s. & & \\
\hline \multicolumn{5}{|c|}{$\begin{array}{l}\text { "p<0.05 significantly different. " } p<0.0 \text { I very significantly different. } p<0.00 \text { I ext- } \\
\text { remely significantly different. APACHE II: Acute Physiology and Chronic Health } \\
\text { Evaluation II; SOFA: Sequential Organ Failure Assessment; SAPS II: Simplified } \\
\text { Acute Physiology Score II; MEDS: Mortality in Emergency Department; n.s.: } \\
\text { Non-specific. }\end{array}$} \\
\hline
\end{tabular}

Within the prediction widths of $10 \%-29 \%$ and $30 \%-49 \%$, the estimated mortality rates of the SOFA and MEDS systems were much higher than the actual mortality rates, whereas those of the APACHE II and SAPS II systems were much closer to the actual mortality rates; when we combined these two prediction widths, the actual mortality rates were within the predicted mortality intervals, i.e., $10 \%-49 \%(46.6 \%$ and 44. $1 \%$, respectively).

Other than prediction accuracy, we also analyzed the predicted mortality rates as limits for mortality risk and observed that predicted mortality rates of APACHE II were superior to those of SAPS II. Therefore, we believe that it is reasonable to accept either APACHE II scores of $>13$ or 17 as a predictor of mortality, as suggested by Yilmazlar et al. or Suwantarat et al,, respectively. ${ }^{[10,11]}$
LRINEC scores of $\geq 6$ may be associated with higher morbidity and mortality rates. ${ }^{[15,16]}$ However, LRINEC scores in survivors and non-survivors were not different in the current study and thus could not be used for predicting the prognosis of necrotizing fasciitis in patients.

Although predicted and actual mortality rates may be different because of the limitation owing to items included, subjected to interpretation and influenced by factors, such as local admission, discharge, and management policies, we observed that the APACHE II and SAPS II scoring systems were superior for predicting the prognosis of necrotizing fasciitis in patients. APACHE II was slightly superior to SAPS II when the predicted mortality rates as limits for mortality risks were compared in pairs. MEDS was originally designed to predict mortality in patients with sepsis at ED. It is considered to be more feasible for ED doctors than the other scoring systems because it has fewer parameters. ${ }^{[17]}$ However, we believe that the MEDS scoring system underestimated the mortality rate because of the exclusion of Glasgow coma scale and biochemical parameters such as sodium, potassium, and creatinine levels and because only a small portion of our patients presented with sepsis. Conversely, SOFA focused on the assessment of organ dysfunction and morbidity whereas APACHE II and SAPS II are designed to predict mortality. ${ }^{[7,8]}$ We believe that the strong feature of APACHE II and SAPS II is that they include Glasgow coma scale and vital parameters such as serum electrolytes levels. Another strong feature of these two scoring systems was the section regarding chronic diseases. Among our patients, the mortality rates were remarkably high among immunocompromized patients, particularly those with hematological malignancies who were prone to mortality.

Even if we included a high number of patients with necrotizing fasciitis in the current study, our results should be validated in multicenter studies with bigger sample sizes. Another limitation is that we did not include updated versions of some scoring systems, such as APACHE IV and SAPS III, in this comparative study.

In conclusion, four predictive scoring systems, namely

Table 6. Comparison of mortality rates and severity scores in the perineum, genitalia, and other body sites

\begin{tabular}{lccr}
\hline & Perineum \& genitalia & Other sites & p \\
\hline Mortality rates & I5/48 (31.3\%) & $7 / 26(26.9 \%)$ & $>0.05$ \\
& Median $(25 \%-75 \%)$ & Median $(25 \%-75 \%)$ & $>0.05$ \\
APACHE II scores & $9(4-17)$ & $8(1-22.5)$ & $>0.05$ \\
SOFA scores & $1.5(0-5)$ & $0.5(0-5.5)$ & $>0.05$ \\
SAPS II scores & $30(20-43)$ & $29(19.5-4 I .5)$ & $>0.05$ \\
MEDS scores & $6(3-9)$ & $6(1.5-9)$ & \\
\hline
\end{tabular}

APACHE II: Acute Physiology and Chronic Health Evaluation II; SOFA: Sequential Organ Failure Assessment; SAPS II: Simplified Acute Physiology Score II; MEDS: Mortality in Emergency Department. 
APACHE II, SOFA, SAPS II, and MEDS, had significantly higher predicted mortality rates for non-survivors than for survivors among patients with necrotizing fasciitis. All the scoring systems underestimated the mortality rates. However, APACHE II and SAPS II were relatively better in estimating mortality for patients with necrotizing fasciitis, although their accuracies remain limited. We believe that there is a requirement to develop a scoring system that is specific to necrotizing fasciitis. The APACHE scoring systems should currently be used rather than the other scoring systems.

\section{Conflict of interest: None declared.}

\section{REFERENCES}

1. Levine EG, Manders SM. Life-threatening necrotizing fasciitis. Clin Dermatol 2005;23:144-7. [CrossRef]

2. Urschel JD, Takita H, Antkowiak JG. Necrotizing soft tissue infections of the chest wall. Ann Thorac Surg 1997;64:276-9. [CrossRef]

3. Shimizu T, Tokuda Y. Necrotizing fasciitis. Intern Med 2010;49:1051-7.

4. Misiakos EP, Bagias G, Patapis P, Sotiropoulos D, Kanavidis P, Machairas A. Current concepts in the management of necrotizing fasciitis. Front Surg 2014;1:36. [CrossRef]

5. Knaus WA, Draper EA, Wagner DP, Zimmerman JE. APACHE II: a severity of disease classification system. Crit Care Med 1985;13:818-9.

6. Le Gall JR, Lemeshow S, Saulnier F. A new Simplified Acute Physiology Score (SAPS II) based on a European/North American multicenter study. JAMA 1993;270:2957,63.

7. Vincent JL, de Mendonça A, Cantraine F, Moreno R, Takala J, Suter PM, et al. Use of the SOFA score to assess the incidence of organ dysfunction/ failure in intensive care units: results of a multicenter, prospective study. Working group on "sepsis-related problems" of the European Society of Intensive Care Medicine. Crit Care Med 1998;26:1793-800. [CrossRef]
8. Ferreira FL, Bota DP, Bross A, Mélot C, Vincent JL. Serial evaluation of the SOFA score to predict outcome in critically ill patients. JAMA 2001;286:1754-8. [CrossRef]

9. Sankoff JD, Goyal M, Gaieski DF, Deitch K, Davis CB, Sabel AL, et al. Validation of the Mortality in Emergency Department Sepsis (MEDS) score in patients with the systemic inflammatory response syndrome (SIRS). Crit Care Med 2008;36:421-6. [CrossRef]

10. Suwantarat N, Chow DC, Koss W, Lin D, Tice AD. Histologically confirmed necrotizing fasciitis: risk factors, microbiology, and mortality in Hawaii. Int J Infect Dis 2012;16:886-7. [CrossRef]

11. Yilmazlar T, Ozturk E, Alsoy A, Ozguc H. Necrotizing soft tissue infections: APACHE II score, dissemination, and survival. World J Surg 2007;31:1858-62. [CrossRef]

12. Kao LS, Lew DF, Arab SN, Todd SR, Awad SS, Carrick MM, et al. Local variations in the epidemiology, microbiology, and outcome of necrotizing soft-tissue infections: a multicenter study. Am J Surg 2011;202:139-45.

13. Gunter OL, Guillamondegui OD, May AK, Diaz JJ. Outcome of necrotizing skin and soft tissue infections. Surg Infect (Larchmt) 2008;9:443-50.

14. Boyer A, Vargas F, Coste F, Saubusse E, Castaing Y, Gbikpi-Benissan G, et al. Influence of surgical treatment timing on mortality from necrotizing soft tissue infections requiring intensive care management. Intensive Care Med 2009;35:847-53. [CrossRef]

15. Su YC, Chen HW, Hong YC, Chen CT, Hsiao CT, Chen IC. Laboratory risk indicator for necrotizing fasciitis score and the outcomes. ANZ J Surg 2008;78:968-72. [CrossRef]

16. Corbin V, Vidal M, Beytout J, Laurichesse H, D'Incan M, Souteyrand P, et al. Prognostic value of the LRINEC score (Laboratory Risk Indicator for Necrotizing Fasciitis) in soft tissue infections: a prospective study at Clermont-Ferrand University hospital. Ann Dermatol Venereol 2010;137:5-11. [CrossRef]

17. Hermans MA, Leffers P, Jansen LM, Keulemans YC, Stassen PM. The value of the Mortality in Emergency Department Sepsis (MEDS) score, $\mathrm{C}$ reactive protein and lactate in predicting 28-day mortality of sepsis in a Dutch emergency department. Emerg Med J 2012;29:295-300. [CrossRef]

\section{ORIJINAL ÇALIŞMA - ÖZET}

\section{Konvansiyonel skorlama sistemleri ile nekrotizan fasiitisli hastalarda mortaliteyi öngörebilir miyiz? \\ Dr. Necdet Fatih Yaşar, ${ }^{1}$ Dr. Mustafa Ufuk Uylaş, ${ }^{1}$ Dr. Bartu Badak, ${ }^{1}$ Dr. Uğur Bilge, ${ }^{2}$ Dr. Setenay Öner, ${ }^{3}$ Dr. Enver İhtiyar, ${ }^{1}$ Dr. Tarık Çağa, ${ }^{1}$ Dr. Ercüment Paşaoğlu ${ }^{1}$}

\section{${ }^{1}$ Eskişehir Osmangazi Üniversitesi Tıp Fakültesi, Genel Cerrahi Anabilim Dalı, Eskişehir Eskişehir Osmangazi Üniversitesi Tıp Fakültesi, Aile Hekimliği Anabilim Dalı, Eskişehir ${ }^{3}$ Eskişehir Osmangazi Üniversitesi Tıp Fakültesi, Biyoistatistik Anabilim Dalı, Eskişehir}

AMAÇ: Bu araştırmada dört skorlama sisteminin (APACHE II, SOFA, SAPS II, MEDS) nekrotizan fasiitisli hastaların prognozlarını doğru tahmin etme yetenekleri karşılaştırıldı.

GEREÇ VE YÖNTEM: Nekrotizan fasiitis tanısı konulan yetmişdört hasta geriye dönük olarak değerlendirildi. Bu skorlama sistemlerinin mortalite tahmin yetenekleri, mortalite gruplarında (sağkalanlar ve ölenler) tahmin edilen mortalite oranları karşılaştırılarak ve ayrıca sağkalanlar ile ölen hastalar arasında mortalite oranları sırasıyla \% 10, \%30 ve \%50'nin üzerinde tahmin edilenlerde gerçek mortalite oranları ikili gruplar halinde karşılaştırılarak değerlendirildi.

BULGULAR: Sağkalanlar ile ölen hastalar arasında tüm skorlama sistemlerinde tahmin edilen mortalite oranları farklıydı. APACHE II ve SAPS II'nin tahmini mortalite oranları gerçek mortalite oranlarına diğer skorlama sistemlerinkinden daha yakındı. Tahmini mortalite oranları mortalite riski için limit değer olarak analiz edildiğinde ise, APACHE II'nin mortalite tahmin yeteneği SAPS II'ninkinden daha üstündü.

TARTIŞMA: Değerlendirilmeye alınan bu skorlama sistemlerinin hepsinde tahmin edilen mortalite oranları, ölenlerde sağkalanlara kıyasla daha yüksekti ancak hepsi de gerçek oranların altında mortalite tahmininde bulundu. Ancak, göreceli olarak APACHE II ve SAPS II nekrotizan fasiitisli hastalarda mortalite tahmininde diğerlerine kıyasla daha üstündü. Mevcut skorlama sistemleri arasında APACHE II'nin kullanılması daha uygun görünmektedir.

Anahtar sözcükler: APACHE II; MEDS; nekrotizan fasiitis; SAPS II; SOFA.

Ulus Travma Acil Cerrahi Derg 2017;23(5):383-388 doi: 10.5505/tjtes.2016.19940 